\title{
The War and the Nature of National Education in the Works of Russian Neokantians
}

\author{
Vladimir Belov \\ Peoples' Friendship University of Russia \\ Moscow, Russia \\ abelovvn@rambler.ru
}

\author{
Julia Karagod \\ Peoples' Friendship University of Russia \\ Moscow, Russia \\ bkaragod_yug@pfur.ru
}

\begin{abstract}
Based on the analysis of works of two Russian thinkers S. Hessen and M. Rubinstein the paper considers the problems of national education. It determines that the First World War served as a specific catalyst for data access issues. Russian Neo-Kantian philosophers, graduates of German universities, did not succumb to the chauvinistic sentiments of the masses and opposed the indiscriminate denial of the presence of human values. On the contrary, they tried to sharpen the dilemma of "national - universal" to allow consistent manner, including in higher education.
\end{abstract}

Keywords-war; national education; human values; $S$. Hessen; M. Rubinstein

\section{INTRODUCTION}

The WWI had not accidently sharpened interest in the issue of National Education. Another peculiar point of this topic is that our attention will be focused on the position of Russian Neokantians, students of German professors and followers of Kant's philosophical tradition. In this position, we face a two-part difficulty that needs to be clarified. First, Russia had entered war against Germany, and former teachers, colleagues and friends became foemen. In addition, Germany, the country of the great philosophical, pedagogical and other cultural heritage had initiated hostilities. Secondly, the social liberal direction of the Kantian philosophy didn't give a reason to Russian followers of Kant's doctrine for a positive or benevolent assessment of the national identity in the educational process.

In fact, in the works of Russian Neokantians, which are devoted to the problems of national education during the WWI, we meet quite a different picture. We have to clarify one more question: whether the Russian Neokantian position on this issue departures from the philosophy of Kant and neo-Kantianism. S.I. Hessen and M.M. Rubinstein represent the leading Russian philosophers Neokantians working in the field of education, whose works has been reviewed in the present paper.

\section{The WAR AND THE PROBLEM OF Human VALUES}

Both Russian philosophers S.I. Hessen and M.M. Rubinstein point out the fact that the war with Germany was

This publication was supported by the Ministry of Education and Science of the Russian Federation (the Agreement number 02.A03.21.0008) a shock for them, since the majority of the representatives of Russian intelligentsia, but at the same time, they didn't succumb to the chauvinistic sentiments of the masses and opposed the sweeping accusations of the German nation in the aggressive and militaristic nature. It is very revealing in the speech of one of the members of the religiousphilosophical society in St. Petersburg, G.A. Vasilevsky at a meeting on March 8, 1915, entitled "Is German culture to blame?" In this speech the author brought the main spiritual principle of German culture, which is the denial of reality. As for the connection of war with this principle, Wasilewski makes the following conclusion: "The denial of reality of militarism has transformed from contemplation area to practical international initiative. And practical suitability were much more effective than the harmonious Kant's system.

German Culture inwardly was untenable. Her claims forced to become the head of history discovered madness of egoistic self-affirmation" [1].

Slavophile V. Ern in his article "From Kant to Krupp" has tried to sum certain philosophical basis for such a negative assessment of the german nation and the german culture. In the article the author presents Kant's doctrine as absolute subjectivity where the subject free to do anything he wants. After release of the mentioned article Rubinstein has almost immediately published a small article in the newspaper "Russian Gazette" where he has compared the russian slavophile position with the German chauvinists, who have consigned to oblivion all the greatest achievements of the german spirit in favor of a massive militaristic psychosis. "It is not about german culture - Rubinstein says, because the essence of a true culture of one. Russia face a great happiness to fight for international law and justice, and we must be willing to not only external victories, but internal cultural victories are extremely important to us as well. That's why you can heartily wish that the acts of vandalism, like the recent raid on Kant, never repeated again" [2].

$\mathrm{S}$. Hessen in his review headlined "Neo-Slavophilism in philosophy" at the Ern's book "The Struggle for the Logos" [See: 3] criticises the entire V. Ern's philosophical system. In this review Russian neokantian philosopher disclose the reasons for the subsequent charges of Russian neo-slavophile German philosophy and especially Kant himself in unleashing war by Germany. The reasons are banal and at 
the same time traditional for the so-called patriots, nationalists of all times: opposition to all other nations, highlighting the achievements of its people as special, different from others. In this case, Ern opposes the nature of Russian and Western ways of thinking, which are expressed the most in the character of philosophizing in the West and East. Hessen clearly shows that all the opposition on such antinomic couples as meonizm - ontologism impersonalism personalism, irreligious rationalism - religious, logizma, aren't able to withstand even superficial criticism and only shows that authors don't have a real philosophical school.

Russian neokantian philosophers regard war as not only an absolute evil and negative phenomena in society and human life, but also the phenomenon that gives a reason to criticize the previous well-established estimates and opinions. The war also has the other side of the coin, where judgments and conclusions appear to be deeper and more thoughtful.

\section{S.I. HESSEN ABOUT THE NATION AND THE NATIONAL EDUCATION}

In particular, S. Hessen in one of his wartime works assumes that talking about the war as fair or unfair phenomenon, assessing the actions of own troops or others troops as needed or criminal, to distinguish true or false patriotism can only clarifying the essence of the nation, national. He was confident that everyone knows what his nation is, and feels that the military operations are not conducted in order to prove the superiority of the forces of one nation over another, but simply a vague understanding, based on the movements of conscience and heart prompts inadequate to talk to the other, for a solid understanding and action. In this case, theoretical development of the problem seems to be needed to make sure of the correctness of the original experience.

So what is the essence of the nation, according to Sergey Hessen? To reveal the contents of the nation Russian philosopher using public and private categories (individual), refers to two logical strategies: opposition and synthesis. In the first case, when the general and the particular are opposed to each other, he points out such socio-philosophical phenomenons as cosmopolitanism and nationalism. In the second case, where the principle of complementarity and mutual penetration of public and private is activated, Hessen enlists the aid of his conception of the creative process in its historical perspective. And he said that alternative to cosmopolitanism - nationalism is based on the mechanical perception of the nation's life, both of alternative members originally suited to his subject, as something given, which has become, truly, without the past and future.

These preliminary considerations already give us understanding how cosmopolitanism and nationalism will be characterized by Russian thinker. In his opinion, cosmopolitan sees no sense in individual nations, they are a historical atavism; all his attention was captured by humanity, a global association of the human race. Such neglect of the private and intoxication of the common leads to situation where cosmopolitan losing a ground, which is a basis for moving forward, and his aspiration for the future turns into the desire for bad infinity. Everything what worth to strive for a happy future is dissapearing.

What would then be the cosmopolitan attitude to the war, and what will become of patriotic feeling, even if we assume that all mankind is fatherland? Russian philosopher answers, without a shadow of doubt: a cosmopolitan rejects any military action, those actions mean the loss of the only possible existence for its integrity, so the war deprived any meaning to him. Therefore, he may fall into either complete indifference, or actively encourage soldiers to defect.

According to S.I. Hessen, nationalists in these matters are worse. That, in contrast to cosmopolitan, breaking the unity of the general and the particular, focuses on the private to the detriment of the whole: nationality and nation mean everything to him, humanity represent a utopian idea, illusion, and even enemy conspiracy.

According to the Russian philosopher, if cosmopolitan's bad infinity arises from the fact that he had nothing to rely on in the present and in the past, it is here and now hangs in a vacuum, then the nationalist bad infinity is closed by past and the present, because he has no future, no purpose, no mission. Therefore, if everything is movement without rest for cosmopolitan, for the nationalist everything is calm without movement.

S. Hessen brings an interesting point about the nationalist. The author who in his work seeks to confine the national peculiarities of its people and denies the cultural experience of the world, is losing its national identity creation. This product of narrow national creativity so loses its depth and specificity that national emasculated completely. This product can be literally absorbed by any nation. The expression "Deutschland über alles" can be easily transformed into the expression "Russia is above all" or "USA above all", the meaning of the utterance of this transformation does not hurt and does not change.

As a result, the nationalists have the only idea of superiority of their nation over all others, Hessen said. So nationalism is inherently warlike and manic: enemies are everywhere and they threaten his nation, the enemies are not only external but also internal. Therefore, nationalist welcomes the war, because he always in state of war, the war is his internal element.

Russian philosopher considers solution of the national question offered by cosmopolitan and nationalist as incorrect and dead-end, because their reasoning is based on false basis of separation of part from a whole or, conversely, the whole from the parts, which inevitably leads to the national organism's death, convert the national organism in mechanism. "This attachment - he stresses - is the main sin of cosmopolitan and nationalist ... They know only a passive attitude to his subject - related only possession" [4].

How to solve the national question, how to determine the essence of the nation? According to Hesse, the only possible way is covered under the concept of creativity. Nation - is the creative process of the nation. It should be noted that the concept of creativity is fundamental to philosophical constructions of S. Hesse. He defines it as "a living unity of 
legends and tasks" [4]. The concepts of "legends" and "tasks" are also important for understanding the russian thinker philosophy. The nation's creativity takes place in close relationship with legends and setting. Tradition in this context defines not just as a past national history and culture, as well as that the past, which is constantly updated and does not die after time. And those national past can only do what it was going to focus on the eternal, absolute values. Therefore, the tasks in the work of the nation, according to Russian philosopher, may only be a national and universal.

As a result, S. Hessen comes to the following conclusion about the nature of creativity of the nation: "Establishment of a national tradition - that's a historic moment in the nation. To proceed from history - his imperative. But the nation - the total work on the supra-historical mission.... The inclusion of national traditions in the catholic tradition of the whole of humanity - that is supra-historical moment in the nation. To strive for the eternal - his imperative" [4].

This author's concept has been criticized for its excessive schematic and simplified representation in perspective of cosmopolitan and nationalist in discussion in Religious and Philosophical Society of St. Petersburg on February 5, 1915. However, some significant objections, moreover, that the author's position is absolutely rationalistic and does not account for an irrational moment in the life of the nation were not expressed.

Another important point that should be noted here is position of S. Hessen regarding pedagogy problems. According to the Russian thinker, the philosopher should be a teacher - it is his philosophical practice. As underlined by one of the authors of this article, "according to Hessen we face the problem of philosophical practice such as difficulty of breeding concepts of practical philosophy and philosophical practice, or a 'specific philosophy'. If practical philosophy is ethics, the philosophical practice - pedagogy" [5].

S. Hessen in his characterization of national education uses the concept of creativity, stories and tasks again, as well as the whole concept of a harmonious personality. According to him, the national education - a process of familiarizing the people of their cultural tradition. And you cannot isolate any specific national value, which is contrary to the need for development of the nation as a "collective identity".

According to Russian thinker human values advocate as the task in the concept of national education. Therefore, national education is a "natural form, the style when people work on human values by necessity" [6].

To clarify this point, Hessen refers to the analysis of related pairs of concepts "national - human". Conflict within this pair of concepts is a reflection of the conflict in the antinomy of "nationalism - cosmopolitanism". Therefore, the Russian philosopher once again clarifies the concept of the nation, which, in his opinion, is "the unique style of the national existence, form, which takes creativity of the people by itself, aimed at resolving universal cultural tasks" [6].

Russian philosopher gives a special role to education language, teaching language, the language of education in the national education. According to Hessen, the language develops with the nation and has certain sense in the communion "of all sections of the population to culture, and in particularly to higher education as its manifestation" [6]. National education should be truly national because "inevitably, grafted from outside that ignores local conditions and local needs in education - whether it's able to break living personality of people, depriving it of the identity and freedom?" - philosopher asks a rhetorical question [6]. Therefore, philosopher consider a "regional pedagogy" as a very important aspect, that is, pedagogy, based on local tradition, local historical and cultural features, local flora and fauna.

\section{M. M. RUbinsteIn ABOUT THE Role OF TRAINING IN NATIONAL EDUCATION}

Another Russian neokantian philosopher - M. Rubinstein emphasizes the need to take in account national specifics in education, as well as striving to supra-national and universal goals and ideals, he believes that efforts should be made for "human prosperity ideals, though their concrete implementation in national dresses or special state form" [7].

Rubinstein emphasizes another specificity of National Education, which allows to update the tradition without sacrificing with human values - this is the fundamental role of education process in any educational space, including space in university education. Analyzing the causes of the war unleashed by Germany, he pointed out the militaristic spirit that has permeated university life in the German education system before the First World War. In German universities, even in teachers environment as Rubinstein notes, was an atmosphere of deification of the army, when being a soldier was considered more valuable than being just a man. "We can say that the modern soldier's Germany, militant people created by the same teacher or, at least, the same teaching, because a teacher by profession and a German officer went hand by hand, and the latter was clearly aware of their own unilateral educational task", - Russian philosopher concludes [7].

M. Rubinstein has realized and noticed cultural differences between Russians and Germans before the war, which were manifested in university education in Germany. As the direct experience of teaching in German universities has taught him, not knowing the language, the nature of everyday life, morals, public preferences becomes an insurmountable obstacle to obtain a full education. Especially because of the fact that education has always regarded itself as a national treasure and German society and German students jealous of foreigners who wanted to assign this [8].

Like S. Hessen, M. Rubinstein emphasizes the close relationship of science, culture and morals, which relies on the integrity of the necessary national and universal values. The war, according to Russian philosopher, clearly demonstrates the high achievements of Germany in the field of science, but the obvious omissions in the protection of human values. The situation in Russia is different, where "Russian society is clearly aware that the idea of man and 
humanity is not forgotten" [9]. However, Russia is losing the science competition with Germany. One of the main reasons for the sad state of affairs in science Rubinstein considers low wages especially of young budding scientists. There is no doubt that this problem is acute and needs to be addressed at all times and any country that cares about their future.

\section{CONCLUSION}

Through the analysis of creativity of two outstanding Russian philosophers and educators, we can answer the questions posed at the beginning of the article:

- Even military action shouldn't lead to the loss of human values. On the contrary, a war forces to look closer at basics of human values, what is the real strength of the mentioned values.

- Russian neokantian philosophers assume that abstract human values that do not have a specific nationalspecific form of expression - lifeless and can't serve people as the ideal of their activities.

- S. Hessen and M. Rubinstein emphasize the presence of the historical tradition, the presence of the national language and the presence of the Master, as the bearer of traditional values and universal values as the specific national features that influence the nature of education in a given country. Important aspects in the context of the problem should include the views of M.M. Rubinstein, who considered an important element in the structure of the teacher's personality, "professional and ethical moment", indissolubly linked with the notion of its priority value foundations of pedagogical work, according to the scientist, the teacher should be regarded as "ideological public service to the cause of deep, sublime vocation" [10].

- The ideas of Russian thinkers remain relevant today, when Russian education strenuously introduced into Western models without any regard to the specifics of the russian specifics, without Soviet education experience; the ideas get even more popular because of wide spread of different forms of learning in the world educational space, where the role of the teacher is reduced to zero, or, at best, to a minimum [11].

\section{REFERENCES}

[1] G. A. Vasilevsky, Is German culture to blame? Religious and Philosophical Society in St. Petersburg (Petrograd): History of the materials and instruments: 1907-1917: vol. 3: 1914-1917. Moscow, 2009, pp. 134-144.

[2] M. M. Rubinstein, Whether Kant is guilty? Rubinstein M.M. About the meaning of life. Works on the value of philosophy, theory of education and university issue. T. II. Moscow, 2008, pp. 325-330.

[3] S. I. Hessen, Neo-slavophilism philosophy, Hessen S.I. Selected works. Moscow, 1998, pp. 71-78.

[4] S.I. Hessen, The idea of nation, Hessen S.I. Selected works. Moscow, 1998, pp. 78-106.

[5] N. Belov, S. I. Hessen in the history of Russian Neoantianism, Kant collection. No. 1, 2014, pp. 59-65.
[6] S. I. Hessen, Pedagogy Basics: Introduction to Applied Philosophy Moscow, 1995, p. 340

[7] M. M. Rubinstein, University and Education, Rubinstein M.M. Abou the meaning of life. Works on the value of philosophy, theory of education and university issue, vol. II, Moscow, 2008, pp. 293-314.

[8] M. M. Rubenstein, On the question of Russian students at German universities, M.M. Rubinstein, About the meaning of life. Works on the value of philosophy, theory of education and university issue, vol. II, Moscow, 2008, pp. 245-256.

[9] M. M. Rubinstein, Stepchildren University (On the training of young scientists), M. M. Rubinstein, About the meaning of life. Works on the value of philosophy, theory of education and university issue, vol. II, Moscow, 2008, pp. 314-325.

[10] M. M. Rubenstein, The problem of teachers. Moscow-Leningrad, 1927, pp. 103-104

[11] O. V. Chistyakova, Rationaliztion of contemporary culture and education in the context of religious resistance to violence // Proceedings of the 2016 International Conference on Arts, Design and Contemporary Education. (ICADCE 2016). Advances in Socia Science, Education and Humanities Research. Moscow, Russia. Paris: Atlantis Press, 2016, vol. 64, pp. 1192-1198. 